\title{
TOTAL LAKE WATER RESOURCES OF THE PLANET
}

\author{
Gurgen P. TAmRAzyan
}

\begin{abstract}
TAmrazyan Gur Gen, P. 1974: Total lake water resources of the planet.
Bull. Geol. Soc. Finland 46, 23-27.

This paper is an attempt to evaluate approximately the amounts of water using the data on Eurasia, and then to give an approximate evaluation for the lake water resources on the Earth as a whole.
\end{abstract}

Gurgen P. Tamrazyan, P.O.Box 189, Baku-Center, USSR.

The total area of the million lakes on the Earth amounts to $2.7 \times 10^{6} \mathrm{~km}^{2}$. It is not easy to evaluate the lake water resources. Nineteen large lakes contain the main mass of lake waters i.e. $158.6 \times 10^{3} \mathrm{~km}^{3}$ of water (Table 1). 15 other large lakes, which are smaller in size but rather well known (Rudolf, Winnipeg, Nicoragua, Van, Venern, Athabasca, Edward, Dead Sea, Balkhash Alberta, Chad, Tana, Geneva, Sevan, Zaysan), contain $1.9 \times 10^{3} \mathrm{~km}^{3}$ of water. Small lakes contain much less water. The total amount of water in the small and smallest lakes is trifling despite the fact that they are so abundant and so large in area. This paper is an attempt to evaluate approximately the amounts of water using the data on Eurasia, and then to give an approximate evaluation for the lake water resources on the Earth as a whole.

The total lake area of the Earth amounts to $2.7 \times 10^{6} \mathrm{~km}^{2}$; the 19 largest lakes account for about $1 \times 10^{6} \mathrm{~km}^{2}$, and all the other several millions of lakes for the remaining $1.7 \times 10^{6}$ $\mathrm{km}^{2}$. Excluding the 6 largest lakes (Caspian,
TABLE 1

Largest lakes of the world (water volume $\geq 300 \mathrm{~km}^{3}$ ).

\begin{tabular}{|c|c|c|c|c|}
\hline $\begin{array}{l}\text { Item } \\
\text { Nos. }\end{array}$ & Lake & $\begin{array}{c}\text { Area, } \\
\left(10^{6} \mathrm{~km}^{2}\right)\end{array}$ & $\begin{array}{c}\text { Water } \\
\text { volume, } \\
\left(\times 10^{3}\right. \\
\left.\mathrm{km}^{3}\right)\end{array}$ & Continent \\
\hline 1. & Caspian Sea . & 0.424 & 76.8 & Eurasia \\
\hline 2. & Baikal ...... & 0.031 & 22.8 & Asia \\
\hline 3. & Tanganyika. & 0.034 & 16.7 & Africa \\
\hline 4. & Superior .... & 0.082 & 12.2 & North America \\
\hline 5. & Nyasa ...... & 0.031 & 5.8 & Africa \\
\hline 6. & Michigan ... & 0.058 & 5.1 & North America \\
\hline 7. & Huron ...... & 0.060 & 4.1 & North America \\
\hline 8. & Victoria .... & 0.068 & 3.0 & Africa \\
\hline 9. & Maracaibo ... & 0.013 & 1.9 & South America \\
\hline 10. & Great Slave. & 0.029 & 1.8 & North America \\
\hline 11. & Issyk-kul' ... & 0.006 & 1.7 & Asia \\
\hline 12. & Ontario ..... & 0.020 & 1.6 & North America \\
\hline 13. & Great Bear .. & 0.030 & 1.3 & North America \\
\hline 14. & Aral Sea .... & 0.066 & 1.0 & Asia \\
\hline 15. & Ladoga ..... & 0.018 & 0.9 & Europe \\
\hline 16. & Titicaca ...... & 0.008 & 0.7 & South America \\
\hline 17. & Kivu ....... & 0.003 & 0.4 & Africa \\
\hline 18. & Erie ....... & 0.026 & 0.3 & North America \\
\hline \multirow[t]{4}{*}{19.} & Onega ...... & 0.010 & 0.3 & Europe \\
\hline & Total & 1.017 & 158.6 & \\
\hline & $\begin{array}{l}\text { Other lakes of } \\
\text { the planet } \\
\text { taken as a } \\
\text { whole .... }\end{array}$ & 1.683 & 7.4 & \\
\hline & Total & 2.7 & 166 & \\
\hline
\end{tabular}


Baikal, Issyk-kul', Aral, Ladoga, and Onega) in Table 1, all the other lakes in the territory of the USSR (2 814723 lakes) account for $0.423 \times 10^{6}$ $\mathrm{km}^{2}$, i.e. $1 / 4$ of the area of all the smaller lakes of the Earth (based on a total of $1.7 \times 10^{6} \mathrm{~km}^{2}$ ). Data obtained within the territory of the USSR and multiplied by a factor of 4 can be used to characterize the water resources of all the minor lakes of the planet. This relation (q) is further substantiated by the fact that about $95 \%$ of the lakes in the USSR and $85 \%$ of their total area are located between the 50 and 75 th northern parallels, i.e. in the same latitudes as and under similar natural conditions (climatic, hydrological, etc.) to those of the overwhelming majority of lakes in other areas of the Earth (Finland, Scandinavia, North America and other areas). Data on the total number of lakes and their areas for the territory of the USSR are presented in Table 2 (the Caspian and the Aral Seas or lakes are excluded).

\section{TABLE 2}

Number and total area of water reservoirs within the territory of the USSR (according to Dubrovin et al., 1971)

\begin{tabular}{|c|c|c|c|}
\hline \multicolumn{2}{|c|}{$\begin{array}{l}\text { Water table area } \\
\qquad\left(\mathrm{km}^{2}\right)\end{array}$} & \multirow{2}{*}{$\begin{array}{c}\begin{array}{c}\text { Number of water } \\
\text { reservoirs (n) }\end{array} \\
2814727\end{array}$} & \multirow{2}{*}{$\begin{array}{c}\begin{array}{c}\text { Total lake area }(\mathrm{S}), \\
\left(\mathrm{km}^{2}\right)\end{array} \\
159532\end{array}$} \\
\hline$<1$ & $\ldots$ & & \\
\hline 1 to 10 & $\ldots$ & 36896 & 87075 \\
\hline 10 to 50 & $\ldots$ & 2124 & 39974 \\
\hline 50 to 100 & $\ldots$ & 234 & 15939 \\
\hline 100 to 1000 & $\ldots$ & 159 & 42324 \\
\hline$>1000$ & $\ldots$ & 26 & 143596 \\
\hline & otal & 2854166 & 488440 \\
\hline
\end{tabular}

Interesting statistical relations (1) are revealed between the depth of a conventional lake belonging to the category under study and the total area of all the lakes covered by this category. These relations have been derived for lakes for which reliable data are available (Table 3 ). For lake categories with areas of 50 to 500 $\mathrm{km}^{2}, 500$ to $5000 \mathrm{~km}^{2}$, and 5000 to $50000 \mathrm{~km}^{2}$ the depth of the conventional lake per $1 \mathrm{~km}^{2}$ of the areas of lakes belonging to a category grows by a factor of about 2 when passing to a group of lakes in a higher category. This relation (1) is
TABLE 3

Average depths of conventional lakes and lake categorys (according to data on the USSR territory)

\begin{tabular}{cc|c|r|r|r}
\hline $\begin{array}{c}\text { Lake } \\
\text { gategory } \\
\left(\mathrm{km}^{2}\right)\end{array}$ & $\begin{array}{c}\text { Number } \\
\text { of } \\
\text { Lakes } \\
(\mathrm{n})\end{array}$ & $\begin{array}{c}\text { Total area, } \\
\mathrm{S}\left(\mathrm{km}^{2}\right)\end{array}$ & $\begin{array}{c}\text { Total water } \\
\text { volume of } \\
\text { lakes (V) } \\
\left(\mathrm{km}^{3}\right)\end{array}$ & $\begin{array}{r}1=\frac{\mathrm{V}}{\mathrm{S}} \\
(\mathrm{m})\end{array}$ \\
\hline $50-500$ & $\ldots$ & 82 & 11663 & 56.3 & 4.8 \\
$500-5000$ & $\ldots$ & 17 & 28691 & 260.3 & 9.1 \\
$5000-50000$ & $\ldots$ & 5 & 117290 & 2381 & 20.3
\end{tabular}

Note: $1=\frac{\mathrm{V}}{\mathrm{S}}$ is the average depth of a conventional lake per $1 \mathrm{~km}^{2}$ of the total lake area for a certain category of lakes $(\mathrm{m})$.

also likely to be valid for lakes with smaller water table areas. Therefore, on the basis of this relation, the following average depths for conventional lakes may be expected: $2.4 \mathrm{~m}$ for the category with an area of $\mathrm{S}=5$ to $50 \mathrm{~km}^{2}, 1.2 \mathrm{~m}$ for the category with an area of $\mathrm{S}=0.5$ to $5 \mathrm{~km}^{2}$, and $0.6 \mathrm{~m}$ for the category with an area of $\mathrm{S}=$ 0.05 to $0.5 \mathrm{~km}^{2}$.

The relation between the average area of one lake from each category of lake areas and the category itself is also an essential factor (Table 4). If the average area of one category is increased by a factor of 10 (when passing from one category to a higher one), the average area of one lake will be about 10 times as large, and will be characterized by the following figure series: $2.4,23.8$ and 266.2. The following relat on is obtained: $\mathrm{K}=2.4 \times 10^{\mathrm{n}}$, where $\mathrm{n}$ is the category of lakes ( $\mathrm{n}=0$ for category $\mathrm{S}=1-10 \mathrm{~km}^{2}, \mathrm{n}=1$ for category $\mathrm{S}=10-100 \mathrm{~km}^{2}, \mathrm{n}=-1$ for category $\mathrm{S}=0.1-1 \mathrm{~km}^{2}$, etc.). This natural relation can be employed for dividing lakes with areas of less than $1 \mathrm{~km}^{2}$ into subcategories (these minor lakes whose area exceeds $2.8 \times 10^{6}$ within the territory of the USSR alone have been calculated in toto; detailed data regarding them are not available). Hence for lakes belonging to category $\mathrm{S}=0.1$ to $1 \mathrm{~km}^{2}$ the average area of one lake will be $0.24 \mathrm{~km}^{2}$, whereas for lakes belonging to category $\mathrm{S}=0.01-0.1 \mathrm{~km}^{2}$ the average area of one lake will be $0.024 \mathrm{~km}^{2}$. This relation (a tenfold increase with respect to the number 2.4) is also valid for lakes belonging to a higher category 
TABLE 4

Area of an average lake in each lake category

\begin{tabular}{|c|c|c|c|c|c|c|}
\hline & $\begin{array}{c}\text { Lake } \\
\text { category } \\
\left(\mathrm{km}^{2}\right)\end{array}$ & $\begin{array}{c}\text { Number of } \\
\text { Lakes } \\
\text { (n) }\end{array}$ & $\begin{array}{c}\text { Total area, } \mathrm{S} \\
\left(\mathrm{km}^{2}\right)\end{array}$ & $\begin{array}{l}\text { Average area } \\
\text { of one lake } \\
\qquad\left(\mathrm{K}=\frac{\mathrm{S}}{\mathrm{n}}\right)\end{array}$ & & Remark \\
\hline $\begin{array}{c}1-10 \\
10-100 \\
100-1000 \\
1000-10000\end{array}$ & 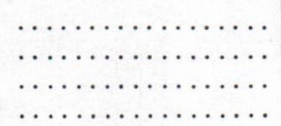 & $\begin{array}{r}36896 \\
2360 \\
159 \\
120\end{array}$ & $\begin{array}{r}87075 \\
55913 \\
42324 \\
304000\end{array}$ & $\begin{array}{r}2.4 \\
23.8 \\
266.2 \\
2530\end{array}$ & $\begin{array}{c}\text { for the } \\
" \prime \prime \\
\text { " " } \\
\text { for the }\end{array}$ & $\begin{array}{c}\text { USSR territory } \\
" \\
" \\
\text { whole Earth }\end{array}$ \\
\hline
\end{tabular}

$\left(\mathrm{S}=1000-10000 \mathrm{~km}^{2}\right.$ ), i.e. the lakes of the whole planet.

The above relations may be used to calculate the total volume of all lake waters within the territory of the USSR (Table 5). The total amount of water in lakes with $\mathrm{S}<1000 \mathrm{~km}^{2}$ is only $770 \mathrm{~km}^{3}$ and the share of lakes of the $\mathrm{S}<1 \mathrm{~km}^{2}$ category is only $121 \mathrm{~km}^{3}$. In addition the USSR has 12 natural lakes of the $S=1000$ to 10000 category with a water volume of $2.27 \times 10^{3} \mathrm{~km}^{3}$ (Issyk-kul', Onega, Sevan, Alakol', Zaysan, Chudskoye, Khanka, Taimyr, Tengiz, Vygozero, Beloye, Chany), 4 lakes of the $S=10000$ to 100000 category with a total water volume of $24.12 \times 10^{3} \mathrm{~km}^{3}$ (Baikal, Ladoga, Balkhash, Aral) and finally teh Caspian Sea with a water volume of approximately $77 \times 10^{3} \mathrm{~km}^{3}$. On the basis of total lake area, the territory of the USSR accounts for more than $1 / 3(35 \%)$ of the surfaces of all the lakes $\left(0.95 \times 10^{6} \mathrm{~km}^{2}\right.$ of $2.7 \times 10^{6}$ $\mathrm{km}^{2}$ ) and for more than $62 \%$ of the lake water volumes of our planet.
As noted above, for the lakes of the $S<1000$ $\mathrm{km}^{2}$ category the total lake area of the whole planet is 4 times as large as the area of the lakes of the same categories located within the territory of the USSR; approximate data for the total area of lakes and their water volumes on the whole planet are presented for the different lake categories in Table 6. The total amount of lake waters on the Earth as a whole is approximately $166 \times 10^{3} \mathrm{~km}^{3}$ (Table 7). Of this amount, the 19 largest lakes account for $95.5 \%$ and the 15 large lakes for $1.2 \%$ of the lake water volume. Thus, the 34 largest and large lakes account for $96.7 \%$ of total amount of lake water resources. The data on these lakes are most exact. The lakes with $\mathrm{S}<1000 \mathrm{~km}^{2}$ account for a total of about $2 \%$ of all lake water volumes; it was particularly for this two per cent and the fractions of it that the various relations mentioned above (q, l, k) were used, and therefore their possible variations cannot have any great effect on the total lake water balance of the planet. These relations were

TABLE 5

Lake water volumes within the USSR territory

\begin{tabular}{|c|c|c|c|c|c|}
\hline \multirow{2}{*}{\multicolumn{2}{|c|}{$\begin{array}{c}\text { Lake } \\
\text { category } \\
\left(\mathrm{km}^{2}\right)\end{array}$}} & \multirow{2}{*}{$\begin{array}{l}\text { Number of } \\
\text { Lakes } \\
\text { (n) }\end{array}$} & \multirow{2}{*}{$\begin{array}{c}\text { Total area, } \mathrm{S} \\
\left(\mathrm{km}^{2}\right)\end{array}$} & \multicolumn{2}{|c|}{ Water volumes, V } \\
\hline & & & & $\left(\times 10^{3} \mathrm{~km}^{3}\right)$ & $\%$ \\
\hline $\begin{array}{c}<1 \\
1-10 \\
10-100 \\
100-1000 \\
1000-10000 \\
10000-100000 \\
>100000\end{array}$ & 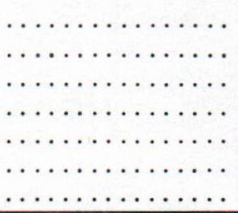 & $\begin{array}{r}2814727 \\
36896 \\
2360 \\
159 \\
12 \\
4 \\
1\end{array}$ & $\begin{array}{rl}159 & 532 \\
87075 \\
55913 \\
42324 \\
43830 \\
133500 \\
424300\end{array}$ & $\begin{array}{r}0.12 \\
0.15 \\
0.20 \\
0.30 \\
2.27 \\
24.12 \\
76.80 \\
\end{array}$ & $\begin{array}{r}0.12 \\
0.14 \\
0.19 \\
0.29 \\
2.18 \\
23.21 \\
73.87\end{array}$ \\
\hline & Total & 2854159 & 946474 & 103.96 & 100.00 \\
\hline
\end{tabular}


TABLE 6

Total evaluation of water resources in minor and medium-size lakes

\begin{tabular}{|c|c|c|c|c|c|c|c|c|}
\hline & $\begin{array}{c}\text { Lake } \\
\text { category } \\
\left(\mathrm{km}^{2}\right)\end{array}$ & $\begin{array}{l}\text { Number of } \\
\text { Lakes } \\
\text { (n) }\end{array}$ & $\begin{array}{l}\text { Total area, } \mathrm{S} \\
\left(\mathrm{km}^{2}\right)\end{array}$ & $\begin{array}{c}\text { Average } \\
\text { Area per } \\
\text { One Lake, } \\
\mathrm{k}=\frac{\mathrm{s}}{\mathrm{n}}\end{array}$ & $1=\frac{\mathrm{V}}{\mathrm{S}}$ & $\begin{array}{c}\text { Water } \\
\text { volume, } \\
\text { V }\left(\mathrm{km}^{3}\right) \\
\text { for the } \\
\text { USSR }\end{array}$ & $q$ & $\begin{array}{l}\text { Total amount } \\
\text { of } \\
\text { Lake Waters } \\
\text { on the Planet }\end{array}$ \\
\hline $0.01-0.1$ & $\ldots \ldots \ldots \ldots \ldots$ & 2389727 & 57353 & 0.024 & 0.5 & 29 & 4 & 116 \\
\hline $0.1-1$ & $\ldots \ldots \ldots \ldots \ldots$ & 425000 & 102000 & 0.24 & 0.9 & 92 & 4 & 368 \\
\hline $1-10$ & $\ldots \ldots \ldots$ & 36896 & 87075 & 2.4 & 1.7 & 148 & 4 & 592 \\
\hline $10-100$ & $\ldots \ldots \ldots$ & 2360 & 55913 & 23.8 & 3.5 & 195 & 4 & 780 \\
\hline $100-1000$ & $\ldots \ldots \ldots$ & 159 & 42324 & 266.2 & 7 & 296 & 4 & 1184 \\
\hline
\end{tabular}

derived on the basis of statistical calculations performed on almost three million lakes. However, as the majority of these lakes are small and located in lowland plain and low-mountain areas, the values presented here characterize primarity such areas; for the mountain areas where the number of lakes is usually not large, the parameters vary and acquire other values. It is interesting to note the variation of the lake size coefficient (f), which is the average total lake area of the region per one lake; $f$ refers to lakes of various categories and $k$ to lakes of a certain category in larger regions (continents, etc.). This coefficient has minimum values $(\mathrm{f}=0.04-0.2)$ when applied to lowland, plain, low-mountain, and high-latitude middle-mountain regions, intermediate values ( $f=0.5$ to 1.1 ) when applied to medium-latitude and low-latitude middlemountain regions, and maximum values $(f=1.3$ to 3$)$ when applied to high-mountain regions.

The distribution of lake waters with respect to sea level is shown in Table 8. The largest percentage of lake waters ( $58 \%$ ) is located below sea level.

Such are the new data on the lake water resources of our planet. The area occupied by lakes

TABLE 7

Total amount of lake waters on the Earth

\begin{tabular}{|c|c|c|c|c|c|}
\hline \multirow{2}{*}{\multicolumn{2}{|c|}{$\begin{array}{l}\text { Lake categories } \\
\text { (lakes or their areas), }\left(\mathrm{km}^{2}\right)\end{array}$}} & \multicolumn{2}{|c|}{ Total Lake water volume } & \multirow{2}{*}{$\begin{array}{l}\text { Number of } \\
\text { Lakes on } \\
\text { the Earth }\end{array}$} & \multirow{2}{*}{ Remark (lakes) } \\
\hline & & $\left(\times 10^{3} \mathrm{~km}^{3}\right)$ & $\%$ & & \\
\hline Largest lakes & $\ldots \ldots \ldots$ & 158.6 & 95.54 & 19 & $\begin{array}{l}\text { Caspian, Baikal, Tanganyika, Su- } \\
\text { perior, Nyasa, Michigan, Huron, } \\
\text { Victoria, Maracaibo, Great Slave, } \\
\text { Issyk-kul', Ontario, Great Bear, } \\
\text { Aral, Ladoga, Titicaca, Kivu, Eri, } \\
\text { Onega. }\end{array}$ \\
\hline Large lakes. & $\ldots \ldots \ldots \ldots$ & 2.0 & 1.20 & 15 & $\begin{array}{l}\text { Rudolf, Vinnipeg, Nicoragua, Van, } \\
\text { Venern, Athabasca, Edwar,, } \\
\text { Dad Sea, Balkhash, Albert, Chad, } \\
\text { Tana, Geneva, Sevan, Zaysan. }\end{array}$ \\
\hline \multirow{7}{*}{\multicolumn{6}{|c|}{ 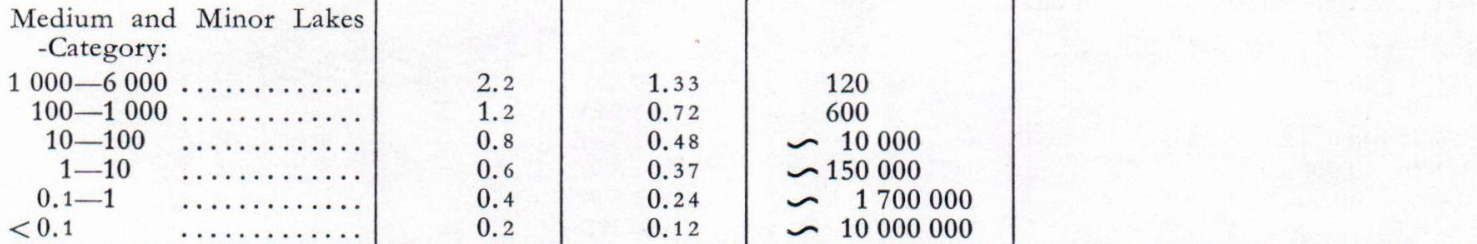 }} \\
\hline & & & & & \\
\hline & & & & & \\
\hline & & & & & \\
\hline & & & & & \\
\hline & & & & & \\
\hline & & & & & \\
\hline & Total & 166 & 100 & & \\
\hline
\end{tabular}


TABLE 8

Distribution of water volumes in the main lakes of the Earth with respect to the oceanic level

\begin{tabular}{|c|c|c|c|c|c|c|c|}
\hline \multirow[b]{2}{*}{$\begin{array}{r}\text { Item } \\
\text { No. }\end{array}$} & \multirow[b]{2}{*}{ Lake } & \multicolumn{3}{|c|}{ Area of Lake $\left(\times 10^{3} \mathrm{~km}^{2}\right)$} & \multicolumn{3}{|c|}{ Total water volume $\left(\times 10^{3} \mathrm{~km}^{3}\right)$} \\
\hline & & $\begin{array}{c}\text { at water } \\
\text { table } \\
\text { level of lake }\end{array}$ & $\begin{array}{l}\text { at oceanic } \\
\text { level }\end{array}$ & at $\frac{0.2 \mathrm{~km}}{\text { level }}$ & $\begin{array}{c}\text { Below } \\
\text { sea level }\end{array}$ & $\begin{array}{l}\text { Above } \\
\text { sea level }\end{array}$ & Altogether \\
\hline 1. & Caspian Sea $\ldots \ldots \ldots$. & 424 & 424 & 112 & 77 & - & 77 \\
\hline 2. & 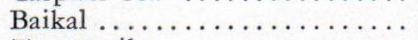 & 31 & 19 & 16 & 11 & 12 & 23 \\
\hline 3. & Tanganyika ............. & 34 & 8 & - & 1.7 & 15 & 16.7 \\
\hline 4. & Superior ............... & 82 & 28 & - & 2 & 10.2 & 12.2 \\
\hline 5. & 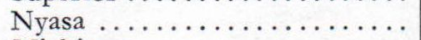 & 31 & 0.6 & 一 & 0.05 & 5.8 & 5.8 \\
\hline 6. & 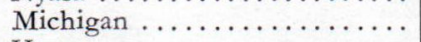 & 58 & 6 & - & 0.2 & 4.9 & 5.1 \\
\hline 7. & Huron $\ldots \ldots \ldots \ldots \ldots \ldots$ & 60 & 0.8 & - & 0.01 & 4.0 & 4.0 \\
\hline 8. & 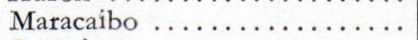 & 13 & 13 & 6 & 1.9 & 一 & 1.9 \\
\hline 9. & Ontario $\ldots \ldots \ldots \ldots \ldots \ldots$ & 20 & 10 & 一 & 0.5 & 1.1 & 1.6 \\
\hline 10. & Aral $\ldots \ldots \ldots \ldots \ldots \ldots$ & 66 & 0.8 & 一 & 0.00 & 1.0 & 1.0 \\
\hline 11. & Ladoga ................ & 18 & 17 & 一 & 0.8 & 0.1 & 0.9 \\
\hline 12. & Onega $\ldots \ldots \ldots \ldots \ldots \ldots$ & 10 & 4 & 一 & 0.1 & 0.2 & 0.3 \\
\hline 13. & Venern $\ldots \ldots \ldots \ldots \ldots \ldots$ & 5 & 1 & 一 & 0.024 & 0.14 & 0.26 \\
\hline 14. & Ded Sea $\ldots . . \ldots \ldots \ldots \ldots$ & 1 & 一 & 1 & 0.1 & 一 & 0.1 \\
\hline & Total & 853 & 532 & 135 & 95 & 54 & 149 \\
\hline
\end{tabular}

$\left(2.7 \times 10^{6} \mathrm{~km}^{2}\right)$ amounts to $0.75 \%$ of that occupied by oceans $\left(361.2 \times 10^{6} \mathrm{~km}^{2}\right)$ whereas lake water resources $\left(0.166 \times 10^{6} \mathrm{~km}^{3}\right)$ amount to only $0.012 \%$ of the volume of oceanic waters $\left(1353 \times 10^{6} \mathrm{~km}^{3}\right)$. In spite of that, lakes provide scenic diversity to the landscape of the Earth and frequently beautify it, thus characterizing the originality and the inimitable picture of the face of our planet among all the other planets of the solar system.

\section{REFERENCES}

Domanitskiy, A. P., Dubrovina, R. G., Isayeva, L. I. (1971) Rivers and Lakes of the Soviet Union. Gidrometeoizdat.

Manuscript received, August 21, 1973. 